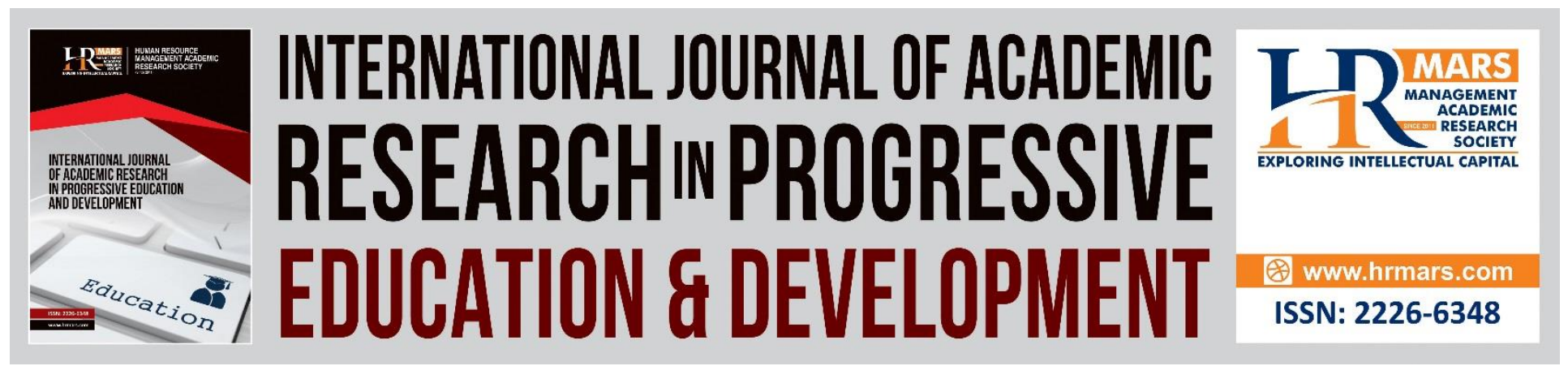

\title{
Attitudes of Primary School Teachers towards the Use of Computerized Educational Games in the Teaching of English Language
}

Nesreen Abdullah Khalifeh Khatatneh, Kamarul Shukri Mat Teh

To Link this Article: http://dx.doi.org/10.6007/IJARPED/v7-i4/4937

DOI: $10.6007 /$ IJARPED/v7-i4/4937

Received: 23 Sept 2018, Revised: 28 October 2018, Accepted: 17 Nov 2018

Published Online: 15 Dec 2018

In-Text Citation: (Khatatneh \& Teh, 2018)

To Cite this Article: Khatatneh, N. A. K., \& Teh, K. S. M. (2018). Attitudes of Primary School Teachers towards the Use of Computerized Educational Games in the Teaching of English Language. International Journal of Academic Research in Progressive Education and Development, 7(4), 280-294.

Copyright: (c) 2018 The Author(s)

Published by Human Resource Management Academic Research Society (www.hrmars.com)

This article is published under the Creative Commons Attribution (CC BY 4.0) license. Anyone may reproduce, distribute, translate and create derivative works of this article (for both commercial and non-commercial purposes), subject to full attribution to the original publication and authors. The full terms of this license may be seen at: $\underline{\text { http://creativecommons.org/licences/by/4.0/legalcode }}$

Vol. 7, No. 4, 2018, Pg. 280 - 294

http://hrmars.com/index.php/pages/detail/IJARPED

JOURNAL HOMEPAGE

Full Terms \& Conditions of access and use can be found at http://hrmars.com/index.php/pages/detail/publication-ethics 


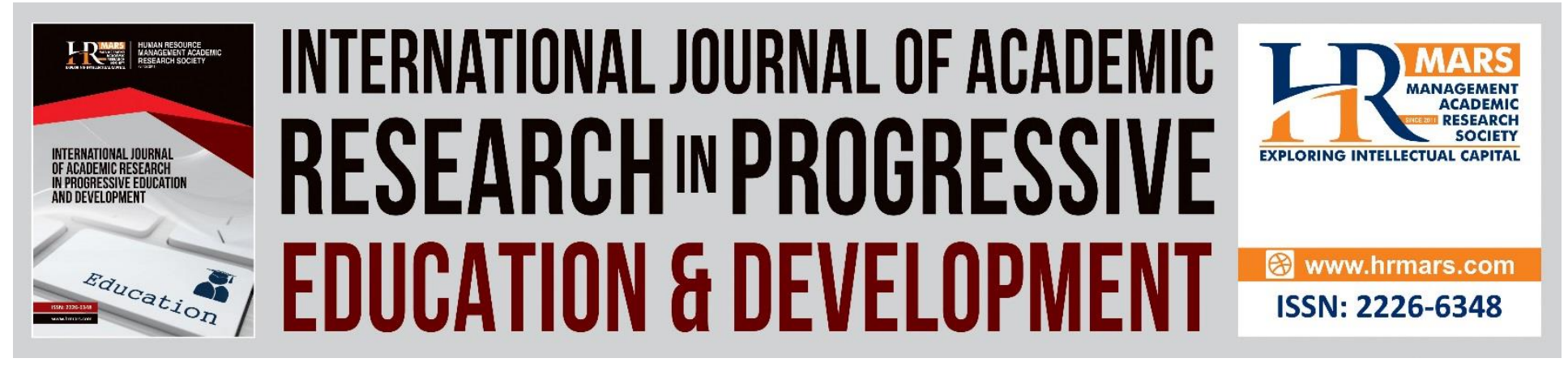

\title{
Attitudes of Primary School Teachers towards the Use of Computerized Educational Games in the Teaching of English Language
}

\author{
Nesreen Abdullah Khalifeh Khatatneh
}

Email: nessren201421@gmail.com

Kamarul Shukri Mat Teh

Email: kamarul@unisza.edu.my

Faculty Of Islamic Contemporary Studies, Universiti Sultan Zainal Abidin, Gong Badak Campus,

21300 Kuala Terengganu, Malaysia

\begin{abstract}
The aim of this study was to identify the attitudes of the primary school teachers towards the use of computerized educational games in the teaching of English language. The study sample consisted of (82) teachers and teachers who study the basic subjects in the English language. A questionnaire was distributed to collect data. The results showed that the attitudes of the primary school teachers towards the use of computerized educational games in the teaching of the English language in the schools of Karak governorate were high and there were statistically significant differences at the level of $(\alpha \leq 0.05)$ in the attitudes of the primary school teachers towards the use of computerized educational games due to the variable of experience in favor of the category less than 5 years, while there were no differences due to gender variables and scientific qualification. In light of the results of the study, the researcher recommends the need to increase the interest of the teachers of the basic stage using computerized educational games in teaching English skills to students.
\end{abstract}

Keywords: Computerized Educational Games, Trends, English Language.

\section{Introduction}

English is an international language that has spread in almost all countries of the world because of its use in business and study, which is one of the means of global and diplomatic communication among peoples in the world.

In many countries of the world, teaching English is a strategic goal that works by all means to achieve this goal. And keep pace with progress and modern technology and that the learner 


\section{DEVELOPMENT}

Vol. 7, No. 4, 2018, E-ISSN: 2226-6348 @ 2018 HRMARS

in childhood can study the foreign language together with the study of the mother tongue (ALAhmadi, 2011: 3).

Electronic educational games are important programs to attract students' attention and try to teach them different concepts. Educational programs can be used in all subjects and for different learners, regardless of their knowledge and age (AL-qazo, 2004: 72).

Educational programs are based on integrating the learning process by playing in a recreation model in which students compete for points. In order to achieve this, the learner needs to solve a mathematical or logical problem; he reads and explains some of the instructions or answers some questions about a topic, In this method, educational games add excitement and motivation to the work of study. Educational games usually take the form that attracts the learner and makes him not leave the game without achieving the desired goal or objectives. It is based mainly on the principle of competition to stimulate the learner's motivation, when it is possible to evaluate the learner's performance through some indirect exercises which increase the likelihood of achieving the lesson objectives (Melhem, 2002: 743).

Educational games are modern means and methods used in the teaching of various subjects such as language, mathematics, science, and sociology (Leonard \& Tracy, 1993: 501), because of the many benefits of its use, especially as we live in the beginning of the twenty-first century, The technological revolution in various fields of life, which calls for the preparation of our children to live up to the realities of this century (Oldfield, 1991: 16-18) by increasing their knowledge and experience in various educational materials (Najem, 2001: 103).

As noted by Nazir (2000: 28) "Educational games are an educational approach that gives children multiple developments. In the context of play, children begin to form certain attitudes towards their growing body, how they use their physical abilities, and to learn certain motor skills such as writing.

The computer is an active medium, which requires the learner to respond actively so that it has an interactive role with the medium during its use, and that these educational aids contribute to raising the efficiency and quality of teaching and contribute to the formation of positive attitudes and helps to remember and retain the information and encourage self-activity (Abbas and Abssi, 2007).

When using the computer in education, it is of great benefit to the learner, including that it provides the educational material at a level appropriate to the abilities of students, and enables the student to choose and implement activities appropriate to his wishes and tendencies in a private atmosphere, and also provides feedback immediately, and there are many benefits to the teacher, which is most important not to repeat the explanation and focus on the work of the teacher as a supervisor and directed, in addition to the benefits of the educational institution (school) and the achievement of self-education, and the development of a technological environment for the development of knowledge employment, through the development of skills Computer use and e-learning (AL-grab, 2003).

There is no doubt that the computer has an important role in the service of education, and one of the reasons that led to the need to use in education the explosion of knowledge and information flow, as the man is looking for a way to save the many information, and retrieval when necessary, where the computer emerged as the best means to lead this purpose, The speed of access to information, because this era is the era of speed, which makes the human need to deal with this huge amount of information, and the sooner and less effort it brings us closer to 

DEVELOPMENT

Vol. 7, No. 4, 2018, E-ISSN: 2226-6348 ๑ 2018 HRMARS

achieving our goals, and was the best way to do so, in addition to Need for skill and Gan in the business performance of complex mathematical operations, where the computer is characterized by the precision and accuracy, and is characterized by the ability to perform all kinds of calculations (Sa'adeh and Sartawi, 2003; Al-Nawayseh, 2007).

Some studies have shown that computer-aided instruction means that these techniques can provide individualized instruction to students directly, and this is where the interaction between these students and the educational programs offered by computer technologies occur. One of the main reasons for the use of computer technologies as an educational tool to counter contemporary changes, which include: population explosion and knowledge, the development of the philosophy of learning and change the role of the teacher, the availability of computers, and the need to learn the computer in all areas of life.

\section{The Problem of the Study}

Through the work of the researcher, a teacher of English for the basic grades, I noticed a general weakness of students in the first grades of their achievement in the English language and may be due to this weakness for several reasons, including the student himself, and there are reasons to the teacher or curriculum.

The use of indoctrination often by the teachers makes the student not participating in the educational process, and is limited to the role of some of the discussions, and this method prevails to move away from the use of methods, models and interactive teaching methods; Which, when used best, can make the student more interactive, positive and participatory (Tahaineh \& Daana, 2013). Many students have difficulty learning English because they are used to traditional methods that are not thrilling; because they learn English in a theoretical way rather than a process that relies on suspense and activating their role in the educational process, while modern educational trends are keen on Avoid traditional methods of teaching, and activate the role of the learner to become the basis of the educational process, it is necessary to use modern educational techniques that take into account technological development.

It was noted that many teachers suffer from the difficulty of mastering computer skills, which have become modern teaching methods rely on it to a large extent, although the Ministry of Education in Jordan has given the training of teachers on the computer very carefully, and created computer courses (ICDL) and granted them However, some teachers, as Awamlah (2012) maintain, have a weakness in the use of computer skills, so they avoid using them in their teaching methods. The school environment is a factor in the poor achievement of students in the English language, in addition to the nature of the curriculum itself, which does not meet the needs of students to teach the language. The use of computer games is superior to the usual learning methods, and the higher the number of students who use the software in Hamid (2014). Based on the above, the problem of the study is determined to identify the attitudes of the primary school teachers towards the use of computerized educational games in the teaching of English language in schools in Karak governorate.

\section{Study Questions}

This study seeks to answer the following questions:

1. What are the attitudes of the primary school teachers towards the use of computerized educational games in the teaching of English language in Karak schools? 

DEVELOPMENT

Vol. 7, No. 4, 2018, E-ISSN: 2226-6348 ๑ 2018 HRMARS

2. Are there statistically significant differences at the level of significance $(\alpha \leq 0.05)$ in the attitudes of primary school teachers towards the use of computerized educational games in the teaching of English language in schools in Karak governorate due to the variables (gender, qualification, experience)?

\section{Objectives of the Study}

The aim of this study is to identify the attitudes of the primary school teachers towards the use of computerized educational games in the teaching of English language in the schools of Karak governorate, to identify the differences in these trends according to the personal and functional variables of the teachers of the study sample (gender, qualification and experience).

\section{The Hypothesis of the Study}

The following zero hypothesis was tested:

$\mathrm{HO}$ : There were no statistically significant differences at the level of significance $(\alpha \leq 0.05)$ in the attitudes of the primary school teachers towards the use of computerized educational games in the teaching of English language in schools in Karak governorate due to the variables (gender, qualification, experience).

\section{The Importance of Studying}

The importance of this study is that it measures the attitudes of teachers towards using an effective method in addressing the weakness of students in the achievement of English Language Educational Games And provide English teachers with an educational tool that will help them achieve their teaching goals and relieve them of the burden of traditional indoctrination, and open wide horizons for the use of computing techniques by teachers in teaching in all schools in the Kingdom of Jordan, Provides a clear vision for officials and decision makers in the Ministry of Education to adopt decisions to address the weakness of students 'learning in English because of traditional teaching methods by promoting teachers' attitudes towards using modern teaching methods such as educational games and encouraging teachers to use educational games Computational Skills in Teaching English Language Reading Skills.

\section{The limits of the Study}

Spatial and temporal boundaries: The study was limited to the schools of the districts of the four Karak governorates (Directorate of Kasaba, Directorate of the Palace, Directorate of Southern Mazar, and Directorate of the Southern Valley). The study will be implemented during the academic year 2017/2018.

Objective Limits: To identify the attitudes of the primary school teachers towards the use of computerized educational games in the teaching of English language in schools in Karak governorate.

\section{Terminology of Study}

Computerized Educational Games: A purposeful, directed, structured, planned, meaningful, student activity in which students make great efforts to achieve the goals of learning skills, in various subjects, and in a variety of fields, within specific rules and regulations described and supervised by the teacher, Is an enjoyable way to train in learning skills, provide incentives for 


\section{INTERNATIONAL JOURNAL OF ACADEMIC RESEARCH IN PROGRESSIVE EDUCATION AND}

DEVELOPMENT

Vol. 7, No. 4, 2018, E-ISSN: 2226-6348 @ 2018 HRMARS

the development of different language skills, and employ some mental processes (Al-heilh and Gnaim, 2002: 598), procedurally defined as games designed and used for the purpose of teaching and developing English language to help basic stage students acquire English language skills through play.

Direction: It is a state of readiness in the individual that prompts him to support or not to support a position (Rashid, 2009, 177). The overall degree of the respondent's response is defined as the answer to the current survey questionnaire.

\section{Previous Studies}

The researcher reviewed the previous studies related to the variables of the subject of the study. The following is a presentation: Al-Barakat and Al-Hassan (2010) studied the aim of identifying the attitudes of the teachers of childhood education towards the use of learning by computerized play in the development of children's learning experiences. (526) teachers and teachers answered the questionnaire distributed, and the semi-formal interview was conducted with (37) teachers and teachers. The results showed positive attitudes in the sample of the study towards the use of computerized toys in the development of children's learning experiences, as well as the absence of statistically significant differences in their positive attitudes according to gender variables, qualifications and teaching experience.

Abu Reish (2013) conducted a study aimed at identifying the effectiveness of a program based on the integrated education in the achievement of the students of the tenth grade in grammar and the direction towards it in Gaza. To achieve the objectives of the study, the researcher used the semi-experimental approach, based on the design of the experimental and control groups, (40) students were divided into two groups; the students of each group were selected as follows: (20) students in the experimental group of the first semester, and (20) students in the control group of the second semester, and the study found that there are statistical differences in the average score of grammar between the students of the experimental and control groups in favor of the experimental group, In addition, there are statistically significant differences in the average scores of students of the experimental and control groups in favor of female students with high and low achievement in the experimental group, Experimental for grammar in favor of the post-application of the trend scale.

Shokri and Abdolmanafi-Rokn (2014) have studied the aim of introducing video games as one of the basic steps of language learning and literacy skills for particular students. In this study, 40 students from two groups in the 14-16 age groups were randomly assigned to the control and experimental groups (each consisting of 20 students). Where participants in the control group receive teaching in the traditional way, while the experimental group was taught using the original computer games. During the teaching period the experimental group worked with each game by the teacher in class. The classroom is equipped with computer, TV, overhead projector, etc. Each week they were exposed to one game. At the end of each course, students were required to play games and extract words and dictate them. After eight sessions, a questionnaire was filled out by participants in the pilot group. The results showed that the experimental group surpassed the control group. This result supports the role and effectiveness of computer video games on student performance in dictation.

Mehrpour \& Ghayour, 2017, conducted a study aimed at identifying the impact of educational computerized games on learning the spelling of English among Iranian children. The 
Vol. 7, No. 4, 2018, E-ISSN: 2226-6348 @ 2018 HRMARS

study was attended by 66 students of Iranian origin, averaging 9.5 years of age, attending the children's section of the Iran Language Institute, the well-run institute run by the state in Iran. These students attended two correct classes. One class was randomly assigned to the experimental group, where students were introduced to a computer educational game called "Spelling Fun". The control group was taught in traditional ways. The results of the data analysis showed that the use of the educational computer game had a significant impact on the language learners in the experimental group. The results showed that the use of the game by the learners in the experimental group, as compared to the learners in the control group, had a significant impact on learning the spelling of English in general and on learning English and English words with silent messages, in particular.

\section{Method and Procedures \\ Study Approach:}

This study is based on the survey method, which describes the reality through the responses of the study society, which examines the reality or phenomenon as it exists in reality. It is concerned as a precise description. It is expressed as a qualitative expression or quantitative expression. It includes an office survey based on references, sources, to build the theoretical framework for the study and the field survey for data collection using the study tool and to analyze it statistically to answer the study questions.

The study population:

The study population consisted of all teachers of the English language studying primary school students in the schools of the four districts of Karak governorate (Directorate of Kasaba, Directorate of the Palace, Directorate of Southern Mazar, Directorate of the Southern Jordan Valley), and they are (82) teachers and teachers.

The study sample:

The teachers of the English language studying the students of the basic stage in the departments of the governorate of Karak (82) were selected teachers and teachers. Table (1) shows the distribution of sample members according to personal variables.

\begin{tabular}{lccc}
\hline Variables & Category & Frequency & percent \\
\hline \multirow{4}{*}{ Gender } & Male & 34 & 41.5 \\
& Female & 48 & 58.5 \\
& Total & 82 & 100.0 \\
Qualification & Bachelor & 47 & 57.3 \\
& Bachelor + Diploma & 22 & 26.8 \\
& Postgraduate & 13 & 15.9 \\
& Total & 82 & 100.0 \\
Experience & Less than 5 years & 26 & 31.7 \\
& 5-10 years & 42 & 51.2 \\
& More than 10 years & 14 & 17.1 \\
& Total & 82 & 100.0 \\
\hline
\end{tabular}

Table (1) shows the following: 
INTERNATIONAL JOURNAL OF ACADEMIC RESEARCH IN PROGRESSIVE EDUCATION AND DEVELOPMENT

Vol. 7, No. 4, 2018, E-ISSN: 2226-6348 @ 2018 HRMARS

- For the gender variable, it appears that the English teachers in the schools of Karak governorate are the most frequent (48\%) in percentage (58.5\%), while the males are the least frequent (34\%) and $41.5 \%$.

- For the variable of the academic qualification, it appears that the teachers of English in the schools of Karak governorate with the bachelor's degree are the most frequent, which reached (47) percentage (57.3\%), while those with postgraduate studies are the least frequent, which reached (13) \%).

- As for the variable of experience, it appears that the English teachers in the schools of Karak governorate, who have between 5-10 years' experience, are the most frequent (42) percentage points (51.2\%), while those who have more than 10 years' experience are the lowest $(14.1 \%)$ and by a percentage of (17.1\%).

\section{Research Instrument}

This study was based on the questionnaire as a tool for collecting data from teachers after reviewing the theoretical literature and the previous studies (Shnaq and Bani Dumi, 2010, Jabr and Jabr, 2007)., And experience. The second part (21) includes paragraphs that measure the attitudes of teachers towards the use of computerized educational games in the teaching of English.

\section{Validity of the Research Instrument}

The credibility of the content (validity of the arbitrators) was confirmed in order to ascertain the veracity of the questionnaire by presenting the questionnaire in its preliminary form to a committee of arbitrators from the teaching staff of Jordanian universities and specialists in the field of teaching methods, measurement, evaluation and educational administration of (5) To ascertain the veracity of the paragraphs of the questionnaire, the accuracy of the linguistic language of the resolution paragraphs, the linguistic accuracy and clarity of the paragraph, the relevance of each paragraph to the questionnaire as a whole, its suitability for the purpose for which it was prepared and any suggestions it deems appropriate to delete, add or modify. , To amend the paragraphs to be amended and to delete the paragraphs to be deleted by the arbitrators based on the consensus of the majority of the arbitrators to make the amendment and to issue the final resolution.

In order to extract the truth indicators for all paragraphs of the questionnaire, they were applied to a sample of 30 teachers from the same study community and to the Pearson Correlation Coefficient correlation between each paragraph and the questionnaire as a whole. Table 2 shows this. 
Vol. 7, No. 4, 2018, E-ISSN: $2226-6348$ @ 2018 HRMARS

Table (2): The correlation coefficients between each paragraph and the axis to which it belongs and its relation to the total score of questionnaires

\begin{tabular}{|c|c|c|c|c|c|}
\hline \multirow[b]{2}{*}{$\begin{array}{l}\text { Paragraph } \\
\text { number }\end{array}$} & Paragraph & \multirow{2}{*}{$\begin{array}{l}\text { Paragraph } \\
\text { number }\end{array}$} & Paragraph & \multirow{2}{*}{$\begin{array}{l}\text { Paragraph } \\
\text { number }\end{array}$} & Paragraph \\
\hline & $\begin{array}{ll}\text { link to } \\
\text { domain }\end{array}$ & & $\begin{array}{ll}\text { link to } \\
\text { domain }\end{array}$ & & $\begin{array}{l}\text { link to } \\
\text { domain }\end{array}$ \\
\hline 1 & $.77^{* *}$ & 8 & $.69 * *$ & 15 & $.78^{* *}$ \\
\hline 2 & $.68 * *$ & 9 & $.78 * *$ & 16 & $.79 * *$ \\
\hline 3 & $.71 * *$ & 10 & $.82 * *$ & 17 & $.72 * *$ \\
\hline 4 & $.58 * *$ & 11 & $.79 * *$ & 18 & $.67 * *$ \\
\hline 5 & $.48^{*}$ & 12 & $.69 * *$ & 19 & $.66 * *$ \\
\hline 6 & $.55^{* *}$ & 13 & $.61^{* *}$ & 20 & $.65^{* *}$ \\
\hline
\end{tabular}

* Acceptable correlation coefficients and function at significance level (0.05)

** Acceptable correlation coefficients and function at significance level $(\alpha \leq 0.01)$

Table (2) shows that the correlation coefficients between each of the paragraphs of "Teachers' attitudes towards the use of computerized educational toys in teaching" and the questionnaire as a whole between (0.48-0.82), are acceptable and relevant correlation coefficients for the application of the study.

\section{Reliability}

The consistency of the questionnaire was determined by applying it to a survey sample of the study population of (30) teachers and teachers. It was applied two times by two weeks on the same survey sample. The Pearson correlation coefficient was calculated between the two applications to extract the stability of the return. The tool extracted the coefficient of stability using the equation Cronbach Alpha (Cronbach Alpha). (0.88), and the stability coefficients of the "Teachers' attitudes towards the use of computerized educational toys in teaching" (0.89), All return stability coefficients were high and acceptable for the purposes of study, Where the coefficient of return stability is acceptable if it exceeds (0.70).

\section{Data Collection}

After the questionnaire was distributed to the teachers who formed the study sample, the questionnaire was delivered to each teacher by hand, and the objectives of the questionnaire were clarified. The questionnaire was collected two days later. After the validity of the tool for statistical analysis, the data was entered into the computer. In order to classify the use of English for computerized learning games in the teaching of English for students of the basic stage, the values of the arithmetic averages of the sample responses of teachers were determined as follows:

1. When the mean of the arithmetic average $=3.68-5$, the attitudes of the primary school teachers towards the use of educational toys are high.

2. When the mean of the arithmetic mean $=3.67-2.34$, the attitudes of the primary school teachers towards the use of educational games are medium.

3. When the mean of the arithmetic average $=2.33-1$, the attitudes of the primary school teachers towards the use of educational games are low. 
Vol. 7, No. 4, 2018, E-ISSN: 2226-6348 @ 2018 HRMARS

\section{Statistical Processing}

In order to answer the research questions, the Statistical Package for Social Sciences (SPSS) was used in the statistical analysis by using descriptive statistical measures to determine trends in the use of computerized educational games in teaching English language based on repetitions, percentages, arithmetic averages, standard deviations and three Way ANOVA.

\section{Results of the Study and Discussion}

Results related to the answer to the first question: What are the attitudes of the basic school teachers towards the use of computerized educational games in the teaching of English language in schools in Karak governorate? To answer this question, the arithmetical averages and standard deviations were calculated for each of the items "Teachers' attitudes towards the use of computerized learning games in the teaching of English" as a whole, and Table 3 shows that.

Table 3: Means and Standard Deviations for Paragraphs of "Teachers' Attitudes toward Computerized Educational Toys in Teaching English Language" and the total score $(\mathbf{N}=82)$

\begin{tabular}{llcccc}
\hline No & Paragraph & Mean & $\begin{array}{c}\text { Standard. } \\
\text { Deviation }\end{array}$ & Rank & $\begin{array}{c}\text { Agreement } \\
\text { Degree }\end{array}$ \\
\hline $\mathbf{2}$ & $\begin{array}{l}\text { Using computerized educational } \\
\text { toys in teaching saves time. }\end{array}$ & 3.83 & 0.91 & 16 & High \\
$\begin{array}{l}\text { The use of computerized learning } \\
\text { games in teaching helps to reduce }\end{array}$ & 3.68 & 0.95 & 19 & High \\
teachers' teaching burden. \\
The use of computerized learning \\
games in teaching increases the \\
effectiveness of students in the \\
classroom.
\end{tabular}


Vol. 7, No. 4, 2018, E-ISSN: 2226-6348 @ 2018 HRMARS

8 The use of computerized learning games in teaching increases the motivation of students to learn.

$\begin{array}{llll}3.84 & 0.91 & 14 & \text { High }\end{array}$

9 The use of computerized educational toys encourages students to think and draw $\begin{array}{llll}3.89 & 1.02 & 13 & \text { High }\end{array}$ conclusions.

10 The use of computerized learning games in teaching helps to develop students' creative skills.

$\begin{array}{llll}3.99 & 0.85 & 8 & \text { High }\end{array}$

11 The use of computerized learning games in teaching helps students to participate and work together.

$\begin{array}{llll}3.94 & 0.87 & 11 & \text { High }\end{array}$

12 The use of computerized learning games in teaching helps to take account of individual differences among students.

13 The use of computerized learning games in teaching helps to change the teacher's role from teacher to

0.96

14

High mentor.

14 The use of computerized educational toys in teaching contributes to improving the quality

$\begin{array}{llll}4.27 & 0.92 & 1 & \text { High }\end{array}$
of teaching.

15 The use of computerized learning games in teaching helps to develop students' problem-solving skills.

$\begin{array}{llll}3.93 & 0.93 & 12 \quad \text { High }\end{array}$

16 The use of computerized learning games in teaching helps simplify the material and make it clearer.

$\begin{array}{llll}4.12 & 0.99 & 3 & \text { High }\end{array}$

17 The use of computerized learning games helps students learn selflearning.

18 The use of computerized learning games in teaching helps to improve learning outcomes.

$\begin{array}{llll}4.22 & 0.89 & 2 & \text { High }\end{array}$

$\begin{array}{llll}4.00 & 0.94 & 6 & \text { High }\end{array}$

19 The use of computerized learning games in teaching is an alternative to using a textbook.

$\begin{array}{llll}4.06 & 0.91 & 5 & \text { High }\end{array}$

20 The use of computerized learning games in teaching helps to effectively evaluate learning. 
INTERNATIONAL JOURNAL OF ACADEMIC RESEARCH IN PROGRESSIVE EDUCATION AND

DEVELOPMENT

Vol. 7, No. 4, 2018, E-ISSN: 2226-6348 ๑ 2018 HRMARS

21 The use of computerized learning games in teaching helps to provide effective feedback to students.

$\begin{array}{llll}4.10 & 0.95 & 4 & \text { High }\end{array}$

\begin{tabular}{llllll}
\hline "Teachers' Attitudes & \multicolumn{1}{c}{ Towards } & & & \\
Computerized Educational Toys in 3.91 & 0.29 & - & High \\
Teaching English Language" as a whole & & & & \\
\hline
\end{tabular}

Table (3) shows that the mathematical averages for the field paragraphs ranged between (3.45-4.27), the highest of which is paragraph (14), which states that "the use of computerized educational games in teaching contributes to improving the quality of teaching" with an average of (4.27) Followed by paragraph (17), which states that "the use of computerized educational games in teaching students to self-learning" is assisted by an average of 4.22 and a high level, and then paragraph (16), which states that "Material and make it more pronounced "with an arithmetical mean (4.12) and a high degree, and in the last paragraph No. (6), which states that "the use of computerized educational games in teaching helps to make education enjoyable and exciting for students" with an average score of 3.45 and a middle grade, the mathematical average of "Teachers' attitudes towards the use of computerized learning games in teaching English" (3.91) to a high degree.

This is due to the fact that teachers, through the use of computerized learning games to teach and develop English language skills, save time, increase the effectiveness of students in the classroom, and increase the ability of students to retain information. The use of computerized learning games in teaching increases the motivation of students to learn, participate and teamwork, and encourage students to think and draw, and develop students' creative skills. It also helps to take into account the individual differences between students through the possibility of choosing the game that suits the level of mental and academic students. The employment of computerized educational games is changing the teacher's role from teacher to mentor through the adoption of self-learning, Computerized educational games also contribute to improving the quality of teaching and learning outcomes, making the material clearer, providing effective assessment and feedback to students, and the ability to remember information more at the time of the exam.

The top paragraphs of the teachers' attitudes towards the use of computerized educational games in the teaching of English were two paragraphs which read: "The use of computerized educational games in teaching students encourages participation and interaction with the classroom." "The use of computerized educational games in teaching makes learning enjoyable and exciting for students "He said. The researcher explains that teaching using electronic educational games contributes to raising the motivation of students to learn, think and draw conclusions. And developing the creative skills of students, and self-learning, in addition to encouraging teamwork among students, which helps teachers to do what is required of them both in the delivery of information and encourages students to learn and retain information and then retrieve when needed and get high grades in the examinations. It is the primary goal that the teacher seeks to use computerized educational games, and the least that states: "The use of computerized educational games in teaching plays an alternative role to the use of textbooks." The researcher justified that the textbook is an integral part of the educational process and is the main reference in obtaining information, and is relied upon to know the information that must 

DEVELOPMENT

Vol. 7, No. 4, 2018, E-ISSN: 2226-6348 ๑ 2018 HRMARS

be obtained by the student, and therefore electronic educational games means that does not communicate the information contained in the book a new form In addition, many schools continue to rely on traditional teaching methods in the light of available resources, which are very few.

This finding is consistent with the result of some studies that showed that the success of EEG use, according to the perceptions of teachers, depends on the characteristics of the teacher and teachers were relatively positive about the success of the use of EEG in both the individual and collective.

Results related to the first question: Are there any statistically significant differences at the level of $(\alpha \geq 0.05)$ in the attitudes of the primary school teachers towards the use of computerized educational games in the teaching of English language in schools in Karak governorate due to the variables (gender, qualification, experience)? To answer this question, ANOVA was applied to detect differences in the attitudes of English teachers towards the use of computerized educational toys in education according to gender, qualification, and experience variables, Table 4 shows.

Table (4) Results of 3 - Way -ANOVA to detect differences in attitudes of English teachers towards the use of computerized educational games in education according to gender, qualification, and experience variables.

\begin{tabular}{lccccc}
\hline $\begin{array}{c}\text { Source of } \\
\text { Contrast }\end{array}$ & $\begin{array}{c}\text { Total } \\
\text { squares }\end{array}$ & $\begin{array}{c}\text { Degrees of } \\
\text { freedom }\end{array}$ & $\begin{array}{c}\text { Average } \\
\text { squares }\end{array}$ & $\begin{array}{c}\mathbf{F} \\
\text { value }\end{array}$ & sig \\
\hline Gender & 0.003 & 1 & 0.003 & 0.039 & 0.843 \\
Qualification & 0.405 & 2 & 0.203 & 2.763 & 0.069 \\
Experience & 0.524 & 2 & 0.262 & 3.575 & 0.033 \\
Error & 5.574 & 76 & .0730 & & \\
Total corrected & 6.870 & 81 & & & \\
\hline
\end{tabular}

Table (4) shows the following:

- There were statistically significant differences at the level of significance (0.05) according to the variable of experience, where the value of (F) (3.575) and statistical significance (0.033), and to detect these differences "Scheffe" test was applied (Table 5) shows that.

- There were no significant differences at the level of significance (0.05) according to the gender variable, where the value of (F) (0.039) and statistical significance $(0.843)$, and there are no significant differences at the level of significance (0.05) depending on the variable qualification, Value (F) (2.763) and statistical significance (0.069).

Table (5): Scheffe test results for detecting differences in the attitudes of English teachers towards the use of computerized educational games in education according to the variable of experience

\begin{tabular}{cccccc}
\hline Experience level & Number & Mean & $\begin{array}{l}\text { Less than } 5 \\
\text { years }\end{array}$ & $\begin{array}{l}5 \text { years - 10 } \\
\text { years }\end{array}$ & $\begin{array}{l}\text { More than } \\
10 \text { years }\end{array}$ \\
\hline $\begin{array}{c}\text { Less than 5 years } \\
5 \text { years - 10 years }\end{array}$ & 26 & 4.042 & - & $* 0.23$ & 0.08 \\
$\begin{array}{c}\text { More than 10 } \\
\text { years }\end{array}$ & 14 & 3.813 & & - & 0.14 \\
\hline
\end{tabular}


DEVELOPMENT

Vol. 7, No. 4, 2018, E-ISSN: 2226-6348 ๑ 2018 HRMARS

Table (5) shows that there are statistically significant differences according to the variable of experience to favor of (less than 5 years) category with an average of (4.04) but an average of ( 5 years -10$)$ category is (3.81).

\section{Recommendations}

In the light of the results reached, the researcher recommends the following:

1. The need to increase the interest of teachers in the basic stage using computerized educational games in teaching English language skills to students.

2. Curriculum developers in the Ministry of Education should develop educational programs in English language to support teaching based on computerized educational games.

3. The Ministry of Education shall provide the facilities and electronic and technological devices necessary for the use of computerized educational games to teach English and develop its skills (reading, writing, listening, and conversation) to students. And provide a special English language laboratory with the equipment and equipment required to teach English in a sophisticated and modern manner in each school.

4. The Ministry of Education shall organize training courses for teachers on the use of computerized educational games in the teaching of English, help teachers to learn new teaching methods and apply modern methods in improving the learning process.

\section{References}

Abu Reish, E. (2013). Effectiveness of a program based on education integrated in the achievement of the students of the tenth grade in grammar and the direction towards it in Gaza, Master Thesis, Islamic University - Gaza.

Al-ahmadi, A. A. (2011). The impact of using educational games in the acquisition of students of the sixth grade primary alphabets and vocabulary of the English language in Jeddah (unpublished master thesis, University of Umm al-Qura, Saudi Arabia).

Al Barakat, A. A. and Hassan, U. M. (2010). Attitudes of child education teachers towards the development of children's educational experiences through computerized educational games. Journal of Educational and Psychological Sciences, 11 (3), 195-230.

Jabr, W. and Wajih, J. (2007). The impact of using computer on the achievement of seventh grade students in mathematics and the attitudes of their teachers towards using it as an educational tool. Unpublished MA, An-Najah National University, Palestine.

Hamid, L. (2014). The Effect of Computer Gaming in Teaching Science to Second Grade Students, Unpublished Master Thesis, University of Damascus, Syria.

Al Hilla, M. M. and Ghanim, A. A. (2002). The Effect of Computerized and Traditional Language Educational Games in Addressing Reading Difficulties among Grade Students, An-Najah University Journal of Research, Humanities, 16 (2). 589-626.

Rashed, M. (2009). Mathematics curriculum and teaching methods for the main classes. Amman: Janadriyah House for Publishing and Distribution.

Sa'adeh, J. and Sartawi, A. F. (2003). Computer and Internet in the fields of Education, Jordan, Amman: Dar Al Shorouk for Publishing and Distribution.

Shnaq, Q. and Bani Dumi, H. (2010). Attitudes of teachers and students towards the use of elearning in Jordanian secondary schools. University of Damascus Journal, 26 (1), 235-271. 
INTERNATIONAL JOURNAL OF ACADEMIC RESEARCH IN PROGRESSIVE EDUCATION AND DEVELOPMENT

Vol. 7, No. 4, 2018, E-ISSN: 2226-6348 @ 2018 HRMARS

Abbas, M. K. and Abssi, M. M. (2007). Curriculum and methods of teaching mathematics for the lower elementary stage Amman, Jordan: Dar Al Masirah for Publishing, Distribution and Printing.

Awamla, K. A. H. (2012), The reality of computer use in teaching from the point of view of principals, teachers and students in Balqa secondary schools, Journal of Studies, Educational Sciences, 39 (2), 428-450.

AL-grab, I. M. (2003). E-Learning: An Introduction to Non-Traditional Training. Egypt: Arab Organization for Administrative Development

AL-qazo, I. (2004). Integrating techniques into education (technically preparing the teacher for the third millennium). Dar Al Qalam Publishers: United Arab Emirates.

Melhem, S. (2002). The use of play in the teaching of scientific concepts and information in mathematics for the fifth grade primary, Journal of King Saud University, Educational Sciences and Islamic Studies, 14 (1), 731-768.

Nazir, N. H. I. (2000), The Effect of Using Educational Games on Collecting and Maintaining First Year Students in Reading and Writing in Madinah, Unpublished Master Thesis, King Abdulaziz University, Madinah Al Munawwarah.

Najem, H. (2001). The impact of the use of educational sports games for the seventh grade students on both their acquisition in mathematics and their attitudes toward them (unpublished master thesis, University of Jordan, Amman, Jordan).

Al Nawayseh, A. (2007). Educational uses of education technology (i 1). Amman: Knowledge Treasures House.

Leonard, L. M., \& Tracy, D. M. T. (1993). Using games to meet the standards for middle school students. Arithmetic Teacher, 40 (9), 499-504.

Mehrpour, S. \& Ghayour, M. (2017). The Effect of Educational Computerized Games on Learning English Spelling among Iranian Children. The Reading Matrix: An International Online Journal, 17(2), 165-178.

Oldfield, B. J. (1991). Games in the Learning of Mathematics: 1: A Classification. Mathematics in School, 20 (1), 41-43.

Shokri, H., \& Abdolmanafi-Rokni, S. J. (2014). The impact of computer games on EFL learners' spelling: A qualitative study. Studies in English Language Teaching, 2 (3), 266-274.

Tahaineh, Y., \& Daana, H. (2013). Jordanian undergraduates' motivations and attitudes towards learning English in EFL context. International review of social sciences and humanities, 4(2), 159-180. 